\title{
Biological Approaches for Control of Root Pathogens of Strawberry
}

\author{
F. N. Martin and C. T. Bull
}

U.S. Department of Agriculture-Agricultural Research Service, 1636 East Alisal St., Salinas, CA 93905.

Accepted for publication 23 July 2002.

\begin{abstract}
Martin, F. N., and Bull, C. T. 2002. Biological approaches for control of root pathogens of strawberry. Phytopathology 92:1356-1362.

Soil fumigation with methyl bromide plus chloropicrin is used as a preplant treatment to control a broad range of pathogens in high-value annual crop production systems. In California, fumigation is used on approximately 10,125 ha of strawberry production to control pathogens ranging from Verticillium dahliae to root pruning pathogens such as

control, fumigation also causes an enhanced growth response of the plant and reduces weed pressure. The development of successful, long-term cost effective biocontrol strategies most likely will require the development of an integrated systems approach that incorporates diverse aspects of the crop production system. Although application of single microbial inoculants may provide some level of control for specific production problems, it will be a challenge to provide the broad spectrum of activity needed in production fields.
\end{abstract} Pythium, Rhizoctonia, or Cylindrocarpon spp. In addition to pathogen
The development of biological approaches for disease control as a replacement to preplant methyl bromide ( $\mathrm{MeBr})$ soil fumigation in annual production systems presents numerous challenges. Fumigation is being used in the first place because it effectively controls yield-limiting pathogens in high-value cropping systems that currently lack economically effective alternatives. Due to the efficacy of fumigation for disease control, entire production systems have been designed around the continued use of $\mathrm{MeBr}$. These production systems are so intertwined with fumigation that limited crop rotation or crop monoculture is often practiced using cultivars that were selected and developed for use in fumigated production systems. The strawberry production system in California is, perhaps, an extreme example of the complexity of the problem encountered when trying to implement biocontrol systems.

Strawberry production in California. Strawberry ranked as the number 11 agricultural crop in the state of California in 1998, with a gross fruit production value of $\$ 750$ million dollars (4). California growers produce $80 \%$ of the U.S. strawberry production on approximately 9,271 ha, which represents approximately half of the total U.S. acreage. California strawberry production dominates the market not only because it is high yielding, but also because the diversity of climates in the state allows strawberries to be harvested virtually year round. Approximately $50 \%$ of California's production is in the central coastal area, with $35 \%$ in southern California and the remaining $15 \%$ in between these two major districts. The production systems in the central coastal region and southern regions of California are different in several respects. Southern California producers target the early season fruit market (December through May or June), with short-day cultivars planted in September/October. Conversely, growers in the central coastal production area target production later in the

Corresponding author: F. N. Martin; E-mail address: fmartin@pw.ars.usda.gov.

Publication no. P-2002-1021-050

This article is in the public domain and not copyrightable. It may be freely reprinted with customary crediting of the source. The American Phytopathological Society, 2002. season, planting both short-day and day-neutral cultivars in October to November, with the harvest season starting in April and generally ending the following September/October.

This highly productive system has been developed over the last 50 years, relying heavily on the use of virus-indexed plant material and soil fumigation for pathogen and nematode control. In the 1950s, growers began to produce back-to-back crops of strawberry on the same land due to the new fumigation technology that had been developed $(39,40)$. Virtually all strawberries in California are currently grown in soil fumigated with $\mathrm{MeBr}$ and chloropicrin (Pic). Historically, one of the primary reasons for soil fumigation was to reduce the incidence of destructive pathogens such as Verticillium dahliae and several Phytophthora spp. In addition to these lethal pathogens, a number of other soilborne fungal pathogens also can contribute to significant losses when crops are grown in nonfumigated fields. For example, in field plots that did not have $V$. dahliae or Phytophthora spp., there was a 25 to $85 \%$ reduction in yield in nonfumigated soil depending on the cultivar; this yield decline was attributed to root rot caused by Pythium, Rhizoctonia, and Cylindrocarpon spp. (F. N. Martin, unpublished data). Because host resistance is currently not a viable option for disease control, the need for finding an alternative to $\mathrm{MeBr}$ soil fumigation in the strawberry production system is acute. With total production costs for the central coastal production area of California approximately $\$ 81,590$ per hectare for the season (16), even minor crop losses or increases in production costs associated with the phase out of $\mathrm{MeBr}$ can have a significant impact on the economic viability of strawberry production in the state.

Alternative disease control methods such as biological, cultural, or chemical measures must be integrated into the larger crop production paradigm. For example, it is possible to reduce the amount of fumigant used for soil treatment or to take advantage of other means for fumigant delivery (such as through the drip irrigation lines) by using bed fumigation in lieu of broadcast fumigation. However, this means that the strawberry bed is covered with plastic the entire production season; depending on the production area, this could disrupt the fruit production cycle. In some areas, the full bed plastic mulch will cause too much 
warming of the beds in the early part of the season, resulting in more vegetative plant growth and reduced levels of fruit production later in the season. Conversely, in other locations, the full bed plastic mulch will reduce fruit production later in the season by warming the mature plant above optimal temperatures for fruit production. Because the early part of the production season also is the rainy season for the area, having the beds covered with plastic also can cause an increase in water run-off into the furrows, leading to a potential increase in soil erosion. Thus, we need to consider all pieces of the production system simultaneously so that we do not create other problems by focusing on just one aspect of production.

Although development of alternatives to $\mathrm{MeBr}$ in commercial fruit production fields is important, a more pressing need is in the nursery operations that produce the transplants for these fields. This industry faces several important challenges with regard to pathogen control in the absence of $\mathrm{MeBr}$ for soil fumigation. If these plants are not produced in a manner that ensures control of soilborne pathogens, production levels in the nurseries will decline and the nursery industry may not be able to provide transplants in adequate numbers for commercial fruit production (17). Furthermore, if the nursery industry is not able to provide clean planting stock for fruit production fields, the task of managing disease in commercial production fields will be even more difficult. It has been suggested that fumigation treatments in the nursery may influence the performance of transplants in production fields (30), although this needs to be examined in greater detail to clarify if infection of transplants by specific root pathogens is what causes reduced productivity in fruit production fields.

Biologically based strategies for disease control. The potential exists to integrate biologically based disease control strategies into an alternative production system for strawberry production, but it will take time to optimize such a system. Because MeBr has been used in the industry for more than 50 years, little is known about the pathogens we are trying to control; understanding the ecology of these pathogens is the first step in managing the diseases they cause. The ecology of other microbial rhizosphere inhabitants is just as important, however, because they may hinder or help our ability to control the pathogens biologically. The goal of a biologically based strategy is to manage the rhizosphere populations to optimize plant growth. This may include enhancing beneficial microbes and reducing deleterious microbes including pathogens.

Identification of yield-limiting diseases. Before concerted attempts can be made for development of biological alternatives for disease control, knowledge of which pathogens are present and contributing to yield reductions in nonfumigated or poorly fumigated fields is needed. In addition to the lethal pathogens $V$. dahliae and several Phytophthora spp., there are complexes of fungal pathogens that can contribute to reductions in plant growth and subsequent yield. The most common of these nonlethal pathogens identified thus far in the central coastal production area of California are Pythium spp., binucleate isolates of Rhizoctonia (AG-A, AG-G, and AG-I) (19), and a Cylindrocarpon spp. (tentatively identified as $C$. destructans; F. N. Martin, unpublished data). There are also a number of other fungal species recovered from necrotic roots that exhibit varying levels of virulence in greenhouse pathogenicity trials. Research is needed to clarify which of these pathogens contribute to growth and yield reductions in field plantings, their distribution in the production area, the time of year that they have the most significant impact on the strawberry plant, the effect of environmental parameters on disease, and the influence of cropping practices on disease severity.

Rhizosphere ecology. Even in the absence of known pathogens, many crops have exhibited an increased growth response when planted into soil that had been fumigated with $\mathrm{MeBr}$ (39). One of the likely reasons for this observation is that fumigation altered the microbial composition of the soil, either enhancing beneficial colonizers or reducing populations of deleterious rhizosphere colonizers. Far from sterilizing the soil, there are still significant populations of soil microbes following fumigation with commercial rates of $\mathrm{MeBr}$ plus Pic. At one test site, even though total bacterial populations were not significantly different in fumigated and nonfumigated soils, MeBr- plus Pic-fumigated soil had 10 to 100 -fold greater populations of fluorescent pseudomonads and 1,000-fold greater populations of total fungi compared with the nonfumigated soil (41). Although differences in total fluorescent pseudomonad populations persisted throughout the season, total fungal populations equilibrated 1 week after fumigation. Given the observed differences in these generalized microbial communities, it is likely that there also will be differences in rhizosphere colonizers as well.

While the subject has not been pursued as rigorously as needed, qualitative differences in rhizosphere colonizers of strawberry grown in MeBr- plus Pic-fumigated soil and nonfumigated soil have been observed. For example, preliminary investigations ( $\mathrm{F}$. $\mathrm{N}$. Martin, unpublished data) indicate that there were differences in the total number of fluorescent pseudomonads (Pseudomonas chlororaphis, Pseudomonas corrugata, Pseudomonas fluorescens, and Pseudomonas putida) recovered from the roots of plants grown in fumigated compared with nonfumigated soil in the early part of the season; this difference between soil treatments moderates as the season progresses (Table 1). Differences also were observed for fungal rhizosphere colonizers, with one field in Watsonville, CA, exhibiting much higher root colonization frequencies by Trichoderma harzianum on plants from fumigated compared with nonfumigated soil (F. N. Martin, unpublished data).

Preliminary investigations evaluating individual components of $\mathrm{MeBr}$ plus Pic and nonfumigated rhizosphere communities indicate that some strains can have beneficial or deleterious effects on the strawberry plant (18; F. N. Martin, unpublished data). In growth chamber studies using environmental conditions paralleling early season field conditions in the central coastal production area of California, one isolate (number 15) reduced root length by $26 \%$ relative to the untreated control, while another isolate (number G-26) increased root length by $138 \%$ (Table 2). Some rhizosphere colonizers were found to enhance berry yield in the field. Trials were conducted in test plots managed by a commercial grower in a field where the predominant pathogen pressure was from generalized root pathogens associated with black root rot such as Pythium, binucleate Rhizoctonia, and Cylindrocarpon spp. (lethal pathogens such as $V$. dahliae or Phytophthora spp. were of limited importance at this site). Plants were treated with the microbial inoculants by root-dipping at the time of planting. In 1998 , one treatment (strain 3) enhanced yield by $35 \%$ relative to the untreated control when the plants were grown in nonfumigated soil (Fig. 1). Unfortunately, in 1999 none of these treatments provided significant improvements in yield compared with the untreated control. One possible reason for this difference in efficacy between years could be the significant differences in the environmental conditions that were observed between these two seasons. Rainfall in the first half of the season was greater in $1998(73 \mathrm{~cm}$ compared with $30 \mathrm{~cm}$ for 1999) and the temperature was warmer (by approximately $4^{\circ} \mathrm{C}$ compared with 1999); this may have

TABLE 1. Rhizosphere populations of total fluorescent pseudomonads recovered from strawberry roots (cv. Selva) at different times of the year enumerated on King's medium B (expressed as CFU per gram of root) ${ }^{\mathrm{a}}$

\begin{tabular}{lccccc}
\hline & \multicolumn{2}{c}{1996 season } & & \multicolumn{2}{c}{1997 season } \\
\cline { 2 - 3 } \cline { 5 - 6 } Treatment & $2 / 8 / 96$ & $3 / 20 / 96$ & & $5 / 24 / 96$ & $12 / 4 / 96$ \\
\hline Fumigated soil & $4.6 \times 10^{6}$ & $1.2 \times 10^{5}$ & & $2.2 \times 10^{5}$ & $1.3 \times 10^{7}$ \\
Nonfumigated soil & $1.3 \times 10^{5}$ & $6.8 \times 10^{4}$ & & $2.9 \times 10^{5}$ & $1.9 \times 10^{6}$ \\
\hline
\end{tabular}

a Differences between soil treatments were significant at $P<0.05$. 
influenced the survival of the inoculants in the rhizosphere, especially considering that inoculation was done once at the time of planting. Additional trials with repeated application of inoculants through the drip lines are in progress.

Attempting to manage soil microflora using biocontrol agents is complex and we must take into account parasitic as well as nonparasitic interactions between the microbes as well as the host. Since the 1980s, the role of deleterious microorganisms on plant growth and health has been demonstrated. Deleterious rhizobacteria (DRB) reduce plant growth and seed germination but are nonparasitic. These DRB can be a major component of bacterial communities in agricultural soils but their negative impacts on plant health can be reduced using biological agents (37).

For the majority of soil microbial inhabitants, tools to study their ecology and elucidate their impact on agriculture have not been developed. This is primarily due to the lack of techniques or difficulty in culturing and enumerating the majority of the microbial biota. The majority of the research to date has concentrated on organisms that are easy to manipulate in culture and therefore our understandings of microbial interactions and their impact on plant health is probably skewed. We are evaluating the ecological significance of mycobacteria, a group of organisms that are not amenable to standard laboratory enumeration techniques and are difficult to work with in culture (C. T. Bull, unpublished data). Myxobacteria are gliding bacteria that undergo cooperative morphogenesis to produce fruiting bodies in starvation conditions. Some of them grow by utilizing cellulose, but many of them feed by secreting antibiotics to kill other microorganisms and producing enzymes to lyse the cells of their prey (26). Despite their ability to prey on other microorganisms and produce a wide range of antibiotics, we are just beginning to explore their role in agriculture. We have isolated myxobacteria from fumigated and nonfumigated soil, as well as from strawberry roots, and are evaluating their interactions with biocontrol agents and pathogens $(8,31)$. Although some organisms are more amenable to study than others, the complexity of the microbial community must be considered when evaluating the impact of the soil microflora on plant health.

Evaluation of isolates from other production systems for biological control. Because of the urgency of finding alternatives to $\mathrm{MeBr}$ and to avoid "re-inventing the wheel," organisms in various stages of commercial development or advanced selections for other cropping systems were tested in field trials. Both fungal

TABLE 2. Effect of microbial inoculants on cv. Selva strawberry plants grown in autoclaved soil for 3 weeks in a growth chamber set with $12 \mathrm{~h}$ diurnal temperature fluctuations of 20 and $10^{\circ} \mathrm{C}^{\mathrm{a}}$

\begin{tabular}{lcc}
\hline & \% Change in growth compared to untreated control \\
\cline { 2 - 3 } Isolate & Shoot & Root \\
\hline 13 & $+22.9^{*}$ & $+46.1^{*}$ \\
14 & +12.1 & $-2.4^{*}$ \\
15 & +8.2 & $-26.0^{*}$ \\
16 & $+25.5^{*}$ & +6.9 \\
17 & $+30.2^{*}$ & +8.2 \\
18 & $+41.0^{*}$ & $+44.1^{*}$ \\
19 & $+39.1^{*}$ & $+40.6^{*}$ \\
20 & $+20.1^{*}$ & $+66.3^{*}$ \\
21 & $+20.6^{*}$ & +12.8 \\
28 & +0.4 & $+34.4^{*}$ \\
47 & $+21.9^{*}$ & $+41.9^{*}$ \\
50 & $+29.3^{*}$ & $+67.7^{*}$ \\
G-1 & $+24.6^{*}$ & $+67.1^{*}$ \\
G-6 & $+31.3^{*}$ & $+56.2^{*}$ \\
G-8 & $+26.8^{*}$ & $+59.2^{*}$ \\
G-10 & +25.3 & $+48.7^{*}$ \\
G-22 & +21.6 & $+115.8^{*}$ \\
G-26 & $+36.3^{*}$ & $+138.2^{*}$ \\
\hline
\end{tabular}

a $*$ indicates that values from the untreated control treatment are significant $(P<0.05)$. and bacterial biocontrol agents, including Gliocladium virens, Pseudomonas chlororaphis, Pseudomonas fluorescens, Pseudomonas aureofaciens, Bacillus cereus, and Streptomyces isolates, were included in the trials. With a few exceptions, all isolates were applied at the time of planting as a root dip. Although these strains failed to provide a consistent increase in shoot growth or yield, the trials were not exhaustive enough to eliminate the possibility of inadequate application (resulting in poor colonization) contributing to the lack of positive results (C. T. Bull and F. N. Martin, unpublished data). Plant growth promotion of strawberries using bacterial inoculants is currently under investigation using several plant growth-promoting rhizobacteria effective in other cropping systems (11). Additionally, six commercially available mycorrhizal inoculants were studied in 2 years of fieldtesting; thus far there appears to be little influence of these commercial inoculants on plant colonization by mycorrhizae or berry yield (9).

Screening and development of effective biological agents for management of soilborne diseases is a labor and capital intensive effort. Alternative approaches to the traditional screening procedures are needed. Approaches that first describe the microbial ecology of fumigated soils and of the strawberry root growing in these soils should provide sound information for targeting screening efforts to identify specific microbes capable of controlling root diseases of strawberry.

Application technologies. Strawberry is a vegetatively propagated crop with all plant material used in commercial fruit production fields originating as bare rooted transplants. All leaves are removed from the plants after harvest from the nursery production fields and they are packed in plastic-lined boxes for shipment to the fruit production fields. Just prior to transplanting, some growers treat with a fungicide mixture (Rovral and Aliette either singly or in combination) to control pathogens that may be on the transplants or in the field soil. This treatment is often done by cutting several corners off the box containing the transplants, filling it with the fungicide mixture, and allowing it to drain out. This type of approach also would be useful for application of microbial inoculants. Alternatively, the inoculants could be applied to the soil just prior to planting or the transplants could be dipped in microbial inoculants prior to being hand planted, although this may present logistical problems because more than 49,400 transplants per ha will need to be treated.

All strawberry production fields in California are drip irrigated. The number of drip tapes per bed varies depending on the soil type and bed width, but generally there are one to two drip tapes

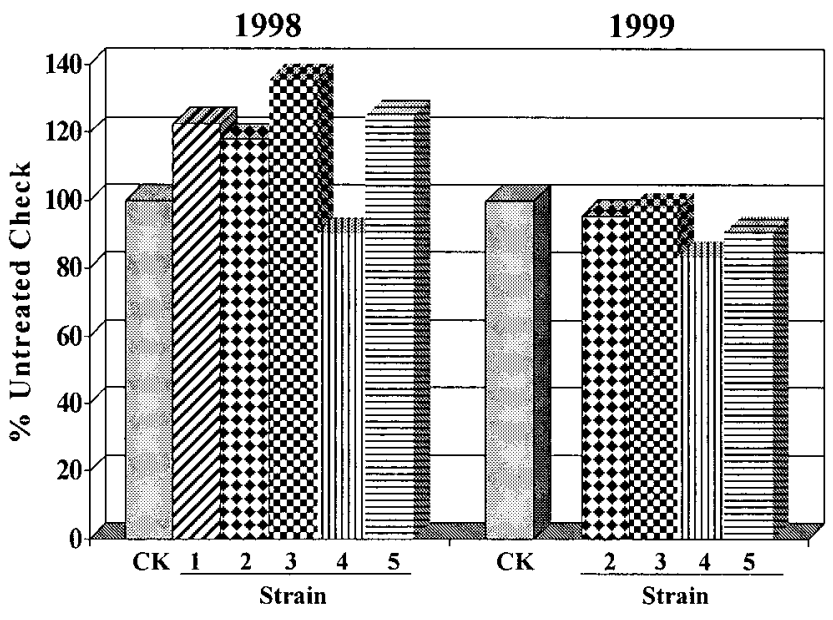

Fig. 1. Marketable yield of strawberry (cv. Selva) grown in a nonfumigated field and inoculated at planting with various microbial inoculants initially recovered from the strawberry rhizosphere. Results are expressed as the percentage of yield obtained in the untreated controls. 
for beds with 130 - to $140-\mathrm{cm}$ centers and three to four drip tapes for beds with 160- to $180-\mathrm{cm}$ centers. Components of the irrigation system are already in place for injection of fertilizers into the drip lines and are amenable for microbial application as well. One major advantage of this type of delivery system is that multiple applications of inoculants can be made throughout the long growing season, with different isolates applied as the season changes or when there is a shift in the importance of particular pathogens. Trials evaluating the efficacy of this type of delivery system for microbial inoculants in strawberry production are currently in progress.

Because the inoculants need to be present in the rhizosphere in adequate numbers to control disease, data are needed to optimize the irrigation system for inoculant delivery. There are a number of factors to be considered for optimization of delivery: spacing and flow rate of the emitters in the drip lines, the distribution of water throughout the bed profile during irrigation, the distribution of roots in the bed profile, the density of the microbial inoculants in the irrigation water needed for control of the pathogens, and the extent of movement of the microbial inoculants through the bed profile during irrigation. These factors are being optimized for delivery of chemical fumigants (1) and will be applicable for development of delivery systems for microbial inoculants as well.

Although there are many advantages of using the drip system for delivery of inoculants, there also are several potential shortcomings. One of the difficulties of using this type of delivery system is the quantity of microbial inoculants that would need to be applied to the field and the logistical problems associated with transportation and storage. One company is attempting to alleviate these problems by developing an automated in-field fermentor that would be capable of producing the inoculum on site and injecting it directly into the drip lines during regularly scheduled irrigations (34). The inoculum formulation also is important, for if particle sizes are too large they will clog the filtration systems or the drip emitters. Likewise, because of the long distances covered by some drip systems, the density of inoculant propagules can influence uniformity of distribution in the field as well; propagules with greater density may settle out in the drip lines before they reach the emitters.

Crop rotation and disease control. Changing production practices may reduce disease severity by several different mechanisms, one of which can be a direct impact on the pathogen. By reducing pathogen inoculum density, disease incidence or severity also may be reduced. For example, crop rotation with broccoli reduces soil populations of $V$. dahliae and the incidence of disease in cauliflower production systems $(35,36,42)$. The efficacy of control is enhanced when the broccoli residue remaining in the field after harvest is chopped into fine pieces with a flail mower prior to incorporation into the soil. A similar effect of broccoli rotations has been observed in strawberry trials as well $(\mathrm{K} . \mathrm{V}$. Subbarao, F. N. Martin, and S. T. Koike, unpublished data). Inoculum densities of the pathogen are reduced to a greater extent when broccoli or brussels sprouts are grown as a rotation crop compared with lettuce (Fig. 2A). This corresponds to lower levels of disease in the field and greater yields (Fig. 2B). While it has been suggested that the mechanism for broccoli-mediated control of this pathogen is "biofumigation" caused by degradation of glucosinolates in the crop residue, the volatile nature of the degradation products is unlikely to be the primary factor causing reductions in the pathogens. This conclusion is based on the observed rates of decline in $V$. dahliae population densities (more gradual in nature, not a sudden reduction that would be expected with biofumigation) and the fact that total populations of Pythium spp. were not affected by crop rotation. Recent evidence appears to suggest that there is a microbial component to this control. In trials where incorporated broccoli residues reduced Verticillium wilt there were 1,000 times greater populations of total bacteria and 100 times greater actinomycete populations in broccoli- amended soil compared with nonamended soil; qualitative differences in community compositions have also been observed (K. V. Subbarao, personal communication).

Organic production. Organic strawberry production is the only system currently adopted by growers that does not use fumigation with $\mathrm{MeBr}$. It has become a viable alternative production system for some California strawberry growers. The number of growers producing certified organic strawberries is increasing steadily. In 1997, $1 \%$ of California strawberries were organically produced (28) and in the years since then strawberry acreage has steadily increased to $5.9 \%$ of the acreage in 2001. According to the California Certified Organic Farmers (CCOF, a California agency that certifies organic production), the number of CCOF strawberry growers has increased from 18 to $34(2,5)$, with a similar increase in total acreage in California.

Organic strawberry production is not a feasible alternative for all growers at this time because a large shift to organic production would result in a price drop that would not support the increases in production costs resulting from greater labor costs and reduced yields. Yields in organic research plots are only 65 to $89 \%$ of the yields achieved by conventional practices that include fumigation $(3,14,27)$. However, one commercial grower has reported yields as high as $95 \%$ of their conventional production fields. Research in

A

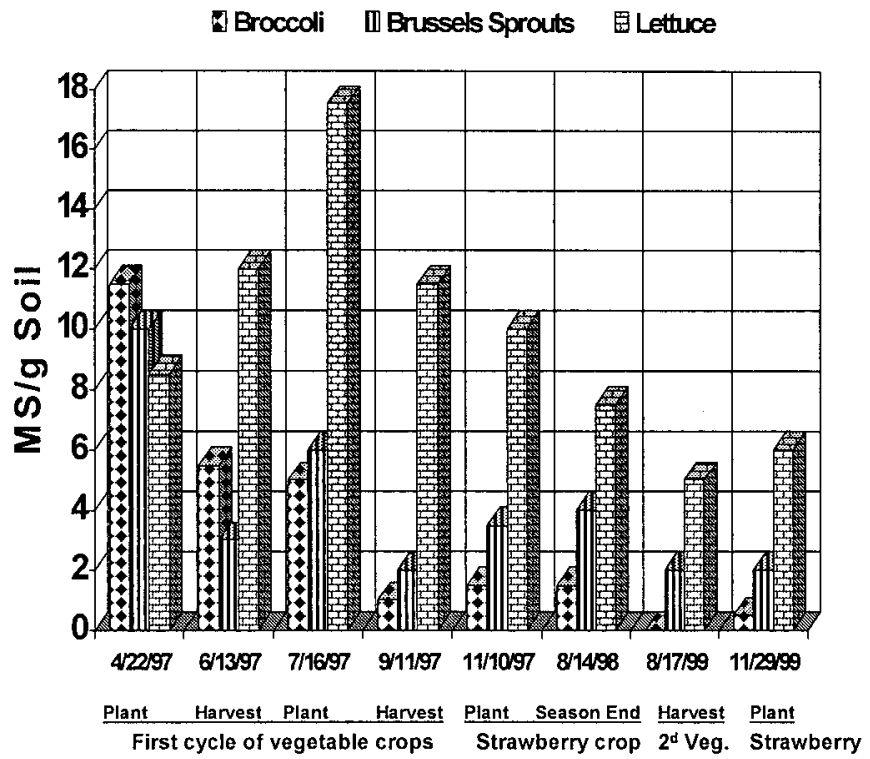

B

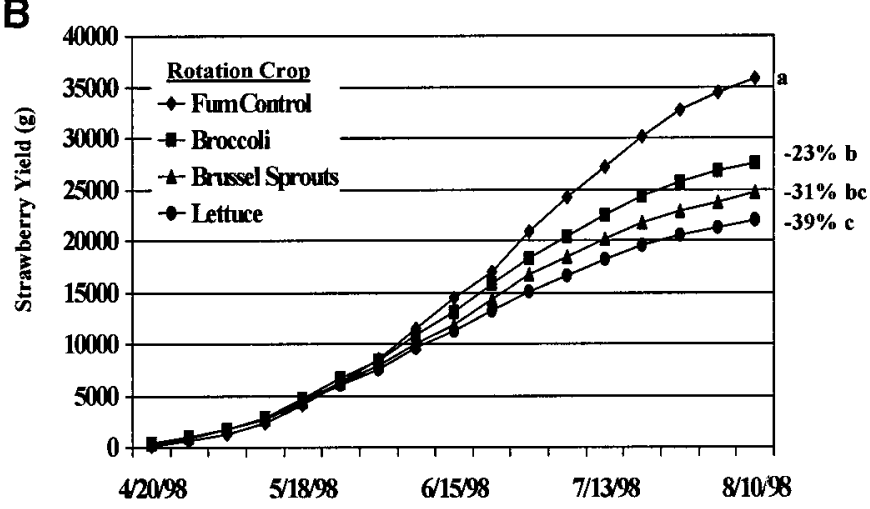

Harvest Date

Fig. 2. A, Effects of crop rotation on inoculum densities of Verticillium dahliae (microsclerotia per gram of soil) and $\mathbf{B}$, strawberry market yield of cv. Selva in test plots in Watsonville, CA. Numbers followed by the same letters are not significantly different $(P=0.05)$. 
almost every aspect of organic production is needed to optimize yield and reduce costs because virtually nothing is known about factors limiting yield in this production system. Additionally, studying this production system can provide insight into problems conventional growers will be facing when $\mathrm{MeBr}$ is no longer available.

Organic growers use a variety of strategies to prevent soilborne plant diseases in their production fields. Crop rotation, use of appropriate cultivars, and clean planting material are the most important approaches used. Organic growers extrapolate from research conducted in conventional production systems, but this can lead to suboptimal choices. For example, although cultivar selection may be the most important factor affecting yield, growers are left to extrapolate from research conducted in conventional systems, which include soil fumigation. It is not surprising that, in the first year of research, the top performing cultivars in organic systems were not always the top performing cultivars predicted by trials in nonfumigated or fumigated conventional production $(\mathrm{C}$. T. Bull, S. T. Koike, and C. Shennan, unpublished data). It is clear that plants are subjected to a different environment (more insects and fewer insecticides for example) in organic fields than they are during cultivar selection in a conventional production system. This may have a significant influence on fruit production.

A cornerstone of disease management in organic production is the use of clean planting material. Because organic growers use the same bare-root transplant material produced in MeBr-fumigated soils as conventional growers, the development of effective alternatives to $\mathrm{MeBr}$ for the nursery industry is of paramount importance for this production system as well. An effort is in progress to move away from using plant material propagated in fumigated soil. One company is producing organic plug transplants that may serve as an alternative source of plants; field evaluations of these transplants are currently in progress (C. T. Bull, unpublished data).

Many of the ecologically based strategies discussed throughout this paper could be used to improve organic strawberry production. In order to optimize organic production however, a research program that parallels the current program in conventional production needs to be conducted in a strictly organic context. While we have minimal knowledge of the soil ecology of pathogens, deleterious agents, and beneficial organisms in conventional strawberry production, we have no information about the same factors in organic strawberry production. There are large differences in the soil ecology of organic and conventional systems. For example, the populations of Pythium spp. were lower in organically managed apple orchards than in conventionally managed ones (24). This may be due to the effect of fumigation on beneficial microbes in conventional systems, but information was lacking to confirm this assumption.

Integrated biological and chemical control. Although many of the fumigants that will be used as replacements do not have the broad-scale biocidal properties of $\mathrm{MeBr}$, they do have a significant impact on many components of the soil microflora communities and may control some of the pathogens that are detrimental to strawberry production. This effect on population dynamics and diversity of the community structures may enhance the potential for establishment of the introduced inoculants. Several bacterial inoculants have been found to induce greater yields when they are used in soil that had been fumigated with low rates of Pic or other fumigants compared with nonfumigated controls or in Picfumigated soil that had not been treated with the microbial inoculants $(10,11,13,25)$. A similar type of enhanced effect on yield is observed when the application of a commercial preparation of T. harzianum follows soil treatment with ozone (J. Duniway, personal communication).

Host tolerance to disease. With the widespread use of $\mathrm{MeBr}$ soil fumigation, many of the potential soilborne pest problems have not generally been a concern in commercial production fields, allowing the breeding efforts to focus on development of cultivars with improved horticultural characteristics and fruit yield. Unfortunately, this has led to the release of cultivars (some of which are widely planted in California) that are susceptible to many of the soilborne pathogens encountered in nonfumigated and organically managed soils. Perhaps the most efficient method for controlling these pathogens would be by selection of tolerant cultivars.

Although there have been attempts to select strawberry cultivars resistant to Verticillium wilt, thus far no resistance to this disease has been identified in commercially acceptable cultivars. More recently, the research has been expanded to evaluate cultivar susceptibility to other soilborne pathogens as well. For example, three different species of Phytophthora (Phytophthora cactorum, Phytophthora citricola, and a Phytophthora fragariae-like species) are encountered in strawberry production in California, and cultivars exhibit a differential susceptibility to these species (6). The cv. Aromas was relatively tolerant of Phytophthora cactorum and Phytophthora citricola, whereas cvs. Diamante and Pajaro were more sensitive to these pathogens. Although not as extensively explored, there appears to be a differential level of cultivar susceptibility to some of the more generalized nonlethal root pathogens such as Pythium spp. and binucleate Rhizoctonia (20). When grown in the greenhouse in pasteurized soil amended with Pythium ultimum at 200 propagules per gram of soil, there was no effect on shoot or root growth for cvs. Selva or Seascape, but there was a $25 \%$ reduction in both growth parameters for $\mathrm{cv}$. Chandler and $50 \%$ for cv. Camarosa. Trials evaluating the effects of this pathogen on field-grown plants are in progress. Likewise, field trials in soil naturally infested with Pythium spp. and binucleate isolates of Rhizoctonia, but disease pressure by $V$. dahliae and Phytophthora spp. was limited or nonexistent, revealed that there was a wide range of effects of these pathogens on plant productivity (20). Cultivars such as Camarosa and Diamante exhibited yield reductions of 45 to $60 \%$ when grown in nonfumigated soil relative to fumigated soil. In contrast, there were limited differences in yield in response to soil fumigation with cv. Capitola.

Clearly, the potential exists for selection of cultivars that are tolerant to soilborne pathogens. Several questions need to be addressed to determine the feasibility of this approach on a broad scale. For example, how much variation in host tolerance will be observed among different species of the same pathogen? The results of Browne et al. (6) indicate there can be a differential response of cultivars to different species of Phytophthora; whether or not this also applies with other pathogenic genera as well remains to be determined. Likewise, is tolerance to one pathogen going to correlate with tolerance to another? For example, will cultivars tolerant to Phytophthora also be tolerant to Pythium or binucleate Rhizoctonia spp.? Lastly, there is a wide range of traits that are selected for in commercial cultivars (plant architecture, fruit shape, size, color, texture, taste, and the cycling of fruit production through the season), and it may be difficult to introgress traits associated with pathogen tolerance into commercially acceptable cultivars.

Disease control in the nursery operations. The above discussion has focused on approaches to employ in commercial fruit producing fields; however, these may not be amenable for use in nursery cropping systems where the transplants are propagated. Of the approximately 1 billion plants produced annually in California, roughly $30 \%$ are exported to other states and countries. Disease control in this production system is of utmost importance because the industry is faced with strict phytosanitary requirements for certification programs associated with plant shipment. Furthermore, if clean plant material is not available to the commercial growers for transplanting into their fruit production fields, attempts to control root diseases in these fields will be all the more difficult. 
The cropping system used in nursery production differs significantly from those used in fruit production. Virus-indexed meristem-propagated plants are first vegetatively propagated by runner production in $\mathrm{MeBr}$ - plus Pic-fumigated soil in a screen house followed by similar vegetative propagation in fumigated soils in a low elevation and then in a high elevation nursery (38). This process generally takes at least 3 years for plants to make it into fruit production fields and strict phytosanitary requirements are encountered at each step. In the low and high elevation nurseries, plants are transplanted without raised beds and are irrigated with sprinklers. As the growing season progresses, the plants produce runners and daughter plants that root and in turn produce more runners and additional daughter plants. This process continues throughout the growing season to a point in which the entire field is covered with strawberry plants. Depending on the cultivar, yields of 494,000 to $1,235,000$ plants per ha can be obtained. The growth habit and density of the plants in the field preclude the entry of tractors or other mechanical implements for cultivation or pesticide application.

Nursery production presents several logistical problems for the use of biological disease control. Effective use of the microbial inoculants is complicated by the need to protect newly formed daughter plants as they are produced throughout the 5 to 6 month growing season. This might require repeated applications of the microbial inoculants. Unlike the fruit production system with its widespread use of drip irrigation, the nursery production systems utilize overhead sprinklers. While it is possible to apply the microbial inoculants through this sprinkler system, the large amounts of inoculants that may be required and the frequency of their application may challenge the cost effectiveness of treatment. Additionally, exposure to UV light can damage microbial inoculants. These factors, including the high level of sanitation that is needed and the consistent, reliable efficacy of control that is required, suggest that implementation of biocontrol strategies in the nursery is faced with significant challenges.

In addition to meeting their phytosanitary needs, transplant producers are interested in producing a value-added product. Application of microbial inoculants to the plants after harvest at the nursery may be an effective way of inoculating the plants prior to transplanting into production fields. Because the plants may be kept for varying periods of time in cold storage (little or no cold storage for short day cultivars and up to several weeks for day neutral cultivars), conditions that did not adversely affect the quality of the plants and were favorable for survival and propagation of the introduced microbial inoculants would have to be developed.

Limitations of biological control in the strawberry production system. It is clear that a variety of factors may limit the success of biological control. Minor changes in the condition of the biocontrol agent, the pathogen, and the environment are important in the efficacy of biological control in other cropping systems (7). In order to use organisms to control disease, we will need to take this into consideration when applying biological control to commercial strawberry production conditions. For example, plant genotype can have a selective effect on the organisms that colonize the rhizosphere (12), and different cultivars may support different populations of organisms responsible for biological control $(32,33)$. To a limited extent, this has been observed with strawberry, with different cultivars exhibiting either a positive or negative interaction with specific mycorrhizal inoculants (15). How this may influence the efficacy of other microbial inoculants for controlling root diseases is unknown, but it is a consideration to keep in mind during the screening and selection process.

Fumigation with $\mathrm{MeBr}$ plus Pic has a wide spectrum of activity and it is unrealistic to think that a single biological agent will mimic this efficacy. It is possible that selection of some microbial inoculants may reduce the incidence and severity of diseases caused by nonlethal general root pathogens such as Pythium and Rhizoctonia spp.; however, development of biocontrol systems for control of Verticillium wilt will likely be more difficult to achieve. In addition to the broad host range of this pathogen, its wide distribution throughout the strawberry production areas, systemic nature of infection, and its ability to survive for long periods of time in the soil, all commercial strawberry cultivars are highly susceptible to this pathogen (29). Disease control is further complicated by the dense root system of the strawberry plant and the several flushes of root growth and development that occur in cycles during the production season that would require repeated colonization of the rhizosphere by the biocontrol agent.

Biological controls for strawberry root diseases are in their infancy. Although several research programs are searching for efficacious isolates, agents that give consistent control of strawberry root diseases under field conditions have not been reported. The development of biological control for management of strawberry root diseases is complicated by variation in the production system used in different parts of the state, the long growing season in which a variety of environmental parameters are encountered, and the wide range of pathogens that can reduce plant productivity. Given that even minor modifications in environmental conditions can influence the efficacy of biological control (7), this may ultimately require that biologically based disease management programs be designed individually for specific production regions rather than for the state as a whole.

\section{CONCLUSION}

Theoretically, soil microflora can be manipulated to improve plant health. There are clear examples of how microbial community management can alleviate plant diseases that limit crop yields in nonfumigated soils $(21-23,25)$. It is accepted that fumigation virtually eliminates pathogens and changes other components of the microflora. Because maximum yields and reduced levels of disease result from fumigation, the microbial communities in those soils might potentially reflect the optimum structure for plant health. It is assumed that by describing the differences between fumigated and nonfumigated soils we should be able to pinpoint beneficial changes that occur during fumigation and mimic the benefits by manipulating the soil microbial community.

Although research evaluating soil microbial ecology of strawberry production started over a decade ago (43), few resources have been devoted to understanding how soil microflora is altered and how this benefits plants in fumigated soil. We still have not adequately described the microbiology of fumigated soils and are in the initial stages of trying to understand how fumigation changes the microbial community. We are a long way from managing these communities. Because of the pending and current restrictions on fumigation with $\mathrm{MeBr}$ and many of the potential alternative fumigants, we have begun a multifaceted effort to characterize the microflora in fumigated and nonfumigated soils. The goal of this research is to understand what factors are beneficial and detrimental to plant health in these soils. In light of the fact that it has taken many years to develop the current highly productive cropping system with an efficient soil biocide as its mainstay, it is unrealistic to think that a similarly productive system based on biological methods of control will be developed in a short period of time.

\section{LITERATURE CITED}

1. Ajwa, H. A., Trout, T., Mueller, J., Wilhelm, S., Nelson, S. D., Soppe, R., and Shatley, D. 2002. Application of alternative fumigants through drip irrigation systems. Phytopathology 92:1349-1355.

2. Anonymous. 1993. California Certified Organic Farmers membership directory. Calif. Certified Organic Farmers, Santa Cruz, CA.

3. Anonymous. 1996. Organic strawberry production as an alternative to methyl bromide. EPA Case Study, Methyl Bromide Alternatives. 
EPA430-R-96-021.

4. Anonymous. 1999. Agricultural statistics. U.S. Gov. Print. Office, Washington, D.C.

5. Anonymous. 1999. California Certified Organic Farmers membership directory. Calif. Certified Organic Farmers, Santa Cruz, CA.

6. Browne, G. T., Becherer, H. E., Vazquez, M. R., and Wakeman, R. J. 1999. Phytophthora control on strawberry, almond, and walnut without methyl bromide. Page 82 in: Proc. Annu. Int. Res. Conf. Methyl Bromide Alternatives and Emissions Reductions.

7. Bull, C. T. 2001. Biological control. Pages $130-135$ in: Encyclopedia of Plant Pathology. O. Maloy and T. Murray, eds. John Wiley \& Sons, New York.

8. Bull, C. T., Shetty, K. G., and Subbarao, K. V. 2002. Interactions between myxobacteria, plant pathogenic fungi, and biocontrol agents. Plant Dis. 86:889-896.

9. Bull, C. T., Stryker, J., Koike, S. T., and Shennan, C. 2000. Use of mycorrhizal inoculants in organic production of strawberries. IFOAM 2000. Basel Switzerland.

10. Duniway, J. M., Hao, J. J., Dopkins, D. M., Ajwa, H., and Browne, G. T. 2000. Some chemical, cultural, and biological alternatives to methyl bromide fumigation of soil for strawberry. Page 9-1 in: Proc. Annu. Int. Res. Conf. Methyl Bromide Alternatives and Emissions Reductions.

11. Eayre, C. 2000. Alternatives to methyl bromide in strawberry and peaches. Page 3-1 in: Proc. Annu. Int. Res. Conf. Methyl Bromide Alternatives and Emissions Reductions.

12. Edel, V., Steinberg, C., Gautheron, N., and Alabouvette, C. 1997. Populations of nonpathogenic Fusarium oxysporum associated with roots of four plant species compared to soilborne populations. Phytopathology 87:693-697.

13. Fravel, D. R. 1996. Interactions of biocontrol fungi with sublethal rates of metam sodium for control of Verticillium dahliae. Crop Prot. 15:115119.

14. Gleisman, S. R., Werner, M. R., Allison, J., and Cochran, J. 1996. A comparison of strawberry plant development and yield under organic and conventional management on the central California coast. Biol. Agric. Hortic. 12:327-338

15. Khanizadeh, S., Hamel, C., Kianmehr, H., Buszard, D., and Smith, D. L. 1995. Effect of three vesicular-arbuscular mycorrhizae species and phosphorus on reproductive and vegetative growth of three strawberry cultivars. J. Plant Nutr. 18:1073-1079.

16. Klonsky, K. M., and De Moura, R. L. 2001. Sample costs to produce fresh market strawberries-central coast region-Monterey and Santa Cruz countries. Univ. Calif. Coop. Ext. ST-CC-01.

17. Larson, K. D., and Shaw, D. V. 2000. Soil fumigation and runner plant production: A synthesis of four years of strawberry nursery field trials. HortScience 35:642-646.

18. Martin, F. N. 1997. Microbial rhizosphere colonizers of strawberry and their effect on plant growth. Page 32-1 in: Proc. Annu. Int. Res. Conf. Methyl Bromide Alternatives and Emissions Reductions.

19. Martin, F. N. 2000. Rhizoctonia spp. recovered from strawberry roots in central coastal California. Phytopathology 90:345-353.

20. Martin, F. N. 2000. Management of root diseases of strawberry. Page 3-1 in: Proc. Annu. Int. Res. Conf. Methyl Bromide Alternatives and Emissions Reductions.

21. Mazzola, M. 1999. Transformation of soil microbial community structure and Rhizoctonia-suppressive potential in response to apple roots. Phytopathology 89:920-927.

22. Mazzola, M. 2000. Impact of wheat cultivation on microbial communities from replant soils and apple growth in greenhouse trials. Phytopathology 90:114-119.

23. Mazzola, M., Granatstein, D. M., Elfving, D. C., Mullinix, K., and Gu, Y.-H. 2001. Cultural management of microbial community structure to enhance growth of apple in replant soils. Phytopathology 92:1363-1366.

24. Mazzola, M., and Levesque, C. A. 1999. Diversity in species composition and sensitivity to metalaxyl among populations of Pythium from apple. (Abstr.) Phytopathology 89(suppl.):S50.

25. Raupach, G. S., and Kloepper, J. W. 2000. Biocontrol of cucumber diseases in the field by plant growth promoting rhizobacteria with and without methyl bromide fumigation. Plant Dis. 84:1073-1075.

26. Reichenbach, H., and Dworkin, M. 1992. The Myxobacteria. Pages 3416-3487 in: The Prokaryotes. A. Balows, H. G. Truper, M. Dworkin, W. Harder, and K.-H. Schleifer, eds. Springer-Verlag, Berlin.

27. Sances, F. V., and Ingham, E. R. 1997. Conventional and organic alternatives to methyl bromide on California strawberries. Compost Sci. Util. 5:23-37.

28. Schneider, S. M., Gingery, R. E., and Vick, K. W. 1998. Evaluation of U.S. EPA case studies: Alternatives to methyl bromide. U.S. Dep. Agric. Agric. Res. Serv. Vol. 1 and 2.

29. Shaw, D. V., Gubler, W. D., Larson, K. D., and Hansen, J. 1996. Genetic variation for field resistance to Verticillium dahliae evaluated using genotypes and segregating progenies of California strawberries. J. Am. Hortic. Sci. 121:625-628.

30. Shaw, D. V., and Larson, K. D. 1999. A meta-analysis of strawberry yield response to preplant soil fumigation with combinations of methyl bromide-chloropicrin and four alternative systems. HortScience 34:839-845.

31. Shetty, K. G., Subbarao, K. V., and Bull, C. T. 2000. Effects of myxobacteria on plant pathogenic fungi and biocontrol agents. (Abstr.) Phytopathology 90(suppl.):S72.

32. Smith, K. P., and Goodman, R. M. 1999. Host variation for interactions with beneficial plant-associated microbes. Annu. Rev. Phytopathol. 37:473-491.

33. Smith, K. P., Handelsman, J., and Goodman, R. M. 1999. Genetic basis in plants for interactions with disease-suppressive bacteria. PNAS 96:4786-4790.

34. Steddom, K. C., and Menge, J. A. 1998. Continuous application of the biocontrol bacterium, Pseudomonas putida 06909, increases soil populations over a single application. (Abstr.) Phytopathology 88(suppl.): S85.

35. Subbarao, K. V., and Hubbard, J. C. 1996. Interactive effects of broccoli residue and temperature on Verticillium dahliae microsclerotia in soil and on wilt in cauliflower. Phytopathology 86:1303-1309.

36. Subbarao, K. V., Hubbard, J. C., and Koike, S. T. 1999. Evaluation of broccoli residue incorporation into field soil for Verticillium wilt control in cauliflower. Plant Dis. 83:124-129.

37. Suslow, T. V., and Schroth, M. N. 1982. Role of deleterious rhizobacteria as minor pathogens in reducing crop growth. Phytopathology 72:111115.

38. Voth, V., and Bringhurst, R. S. 1990. Culture and physiological manipulation of California strawberries. HortScience 25:889-892.

39. Wilhelm, S., and Paulus, A. O. 1980. How soil fumigation benefits the California strawberry industry. Plant Dis. 64:264-270.

40. Wilhelm, S., Storkan, R. C., and Sager, J. E. 1961. Verticillium wilt of strawberry controlled by fumigation of soil with chloropicrin and chloropicrin-methyl bromide mixtures. Phytopathology 51:744-748.

41. Xiao, C. L., and Duniway, J. M. 1998. Bacterial population response to soil fumigation and their effects on strawberry growth. (Abstr.) Phytopathology 88(suppl.):S100.

42. Xiao, C. L., Subbarao, K. V., Schulbach, K. F., and Koike, S. T. 1998. Effects of crop rotation and irrigation on Verticillium dahliae microsclerotia in soil and wilt in cauliflower. Phytopathology 88:1046-1055.

43. Yuen, G. Y., Schroth, M. N., Hancock, J. G., and Weinhold, A. R. 1988. Differential effects of various preplant soil treatments on the root microflora, root growth and yield of strawberry. (Abstr.) Phytopathology $78: 1545$. 